\title{
THE UKRAINIAN DANCE ON THE STAGE AND IN THE HOUSEHOLD CULTURE OF THE NATION: CURRENT ISSUES
}

\section{Olha Boiko}

\section{INTRODUCTION}

The construction of a modern society in post-colonial Ukraine has peculiarities in the aspect of culture, in particular choreographic, due to historical factors. Describing the XIX century as a unique period of national history, G. Skrypnyk emphasizes: "The decisive role in the preservation of ethnicity and in the national solidarity processes of the society was played by ethnic culture, which came under this time a fully developed, holistic system with peculiar characteristic features of its genres and artistic and stylistic characteristic"1. The artistic values of ethno culture were largely preserved and developed in the folk-stage choreography of the Soviet era, when, by changing ideological accents, the government tolerated the populist traditions of the XIX - early XX centuries. In the era of state independence, Ukrainian choreographic culture entered, preserving the rich artistic heritage of the past, often lost by developed countries of Western Europe. The new cultural reality is characterized by the overcoming of the ethnography inherent elements in the populist approach, as well as the rudiments of the leveling national identity of the "socialist realism method", but the scientific community has not yet developed a consolidated opinion on the role and place of folk choreography in a modern model of the culture. This leads to a deeper study of the problem of preserving and developing the national choreographic heritage in the context of the leveling impact of globalization, and leads to the idea that the answer to the question: "What is contemporary choreography?" foreign dances, but also in the complex interaction of traditions and innovations, ambiguous, diverse and multifaceted transformation of folk dance, in general, the transformation of cultural codes and regional and local cultural canons.

Turning to the corner in choreology problem of the traditions interaction and innovations, Ukrainian researchers reject unilateral approaches; in particular, formed in Soviet art studies under the influence of ideological factors, interpret the dialectics of the interaction of traditions and innovations as the driving force

\footnotetext{
${ }^{1}$ Skrypnyk, H.A. (2008). Istoriia ukrainskoi kultury: u 5 tomakh. T. 4. Kn. 1. Kyiv: Naukova dumka.
} 
for the development of national culture. "Innovation is not a radical denial or destruction of a tradition and it can be an improvement or refinement of it," $\mathrm{K}$. Kyrylenko notes. - Tradition, in its turn, is not something that remains unchanged, tradition is not synonymous with archaisms or retrograde"2. In the context of innovation, emphasizes the researcher, the interaction of tradition and innovation is transformed into a constructive dialogue, forming an innovative culture. In this context, the contemporary choreographer is seen as the subject of innovative processes, in the professional activity of which the dialogue of tradition and innovation "is the basis for the search for new forms and contents in the contemporary cultural and artistic space"3. As a successful example of innovation, K. Kyrylenko cites the contemporary dance that emerged at the beginning of the $21^{\text {st }}$ century as a synthesis of modern and postmodern dance with various techniques of oriental physical education schools (yoga, aikido, etc.). In our opinion, no less successful example of an innovative approach on the basis of Ukrainian culture is the creation of "Fighting Hopak" is a kind of reading of the iconic folk dance as a dance of the modern, and at the same time is as encrypted in its movements of a holistic system of psychophysical improvement created by the Zaporozhye Cossacks. "Fighting Hopak" was created in the late 1980s and became widely known among the Ukrainian youth, its recognition in the status of modern dance is confirmed by the authoritative opinion of M. Vantukh ${ }^{4}$.

Centuries-old traditions of Ukrainian folk choreography are distinguished by regional and local originality: the dances of the steppes differ from the dances of Polishchuk and Gorjan, even in the swords of one region, for example, the Carpathian, the dances of Hutsuls, fights and lemmas have distinct differences. However, throughout the variety of dance forms, Ukrainian choreography developed on the basis of common archetypes, a single macro-cultural code, and the principle of unity in diversity, which defined the role of folk dance as a powerful means of establishing Ukrainian identity. Understanding this role of folk dance is growing in the professionals minds and the general public after the Revolution of Dignity, in view of the circumstances of the "hybrid war", whose purpose in spiritual and cultural aspect is to eliminate identity. In today's struggle for Ukrainian dance, in

2 Kyrylenko, K.M. (2016). Tradytsii ta novatsii yak skladova innovatsiinoi kultury maibutnoho khoreohrafa. In Khoreohrafiia XXI stolittia: mystetskyi ta osvitnii potentsial: materialy Vseukrainskoi naukovo-praktychnoi konferentsii (m. Kyiv, 15-16 kvitnia 2016 r.). Kyiv: KNUKiM (pp. 17-20).

${ }^{3}$ Ibid.

${ }^{4}$ Burkovskyi, O. (2013). Zavzhdy v dorozi: Dokumentalna povist pro M. Vantukha. Kyiv: Presa Plius. 
addition to the challenges posed, new challenges are emerging that require theoretical reflection and an adequate and timely response from society.

\section{Topical issues of choreographic thought}

The culture of Ukraine, the territory of which for many centuries was divided between different states, developed under unfavorable conditions, under the influence of dominant cultures. This led, in particular, to the delayed, in comparison with other European peoples, the formation of scientific reflection on Ukrainian folk dance as an object of special research. The records of choreographic folklore made in the 19th - early 20th centuries by V. Hnatyuk, B. Grinchenko, P. Chubinsky, P. Shcheryk-Donykiv, B. Shukhevych, Polish ethnologist V. Shukhevych had mostly fragmentary characters, as were records of folk folklore, as well as records of folk folklore. The first "Theory of Ukrainian Folk Dance" by V. Verkhovynts appeared only in $1920^{5}$. The systematic development of Ukrainian choreographic art criticism in the Soviet era was significantly hampered by numerous restrictions and prohibitions. Its works were taken by K. Balog, M. Vantukh, K. Vasylenko, V. Verkhovynets, P. Virsky, O. Gomon, A. Gumenyuk, B. Kolnohuzenko, A. Krivokhizhi. Notable phenomenon was the publication of K. Vasylenko's fundamental work "The Lexicon of Ukrainian Folk Dances", which had no analogues in Soviet art criticism. It first substantiated a number of theoretical and methodological problems that are important for the development of national folk-stage choreography.

The main task of post-Soviet Ukrainian choreology was to critically rethink the theoretical framework created by its predecessors from the standpoint of historicism and scientific objectivity, using the latest methodological approaches. In general, the directions of modern chorological studies ${ }^{6}$ have been identified, which in a new way reveal the historical, cultural, theoretical, methodological and pedagogical aspects of the formation and Ukrainian folk development and folk choreography. The filling process the "white spots" is ongoing, that is, the return to scientific circulation of works removed from ideological considerations, biographical materials about prominent figures of national culture whose names were banned in Soviet times are published. Choreology is becoming an increasingly important component of national

${ }^{5}$ Verkhovynets, V. (1990). Teoriia ukrainskoho narodnoho tantsiu: 5-te vyd., dopovnene. Kyiv: Muzychna Ukraina.

${ }^{6}$ Kozynko, L.L. (2016). Zberezhennia folklornykh tantsiuvalnykh tradytsii u praktytsi profesiinykh khoreohrafichnykh kolektyviv zakhidnoho rehionu Ukrainy. In Khoreohrafiia XXI stolittia: mystetskyi ta osvitnii potentsial: materialy Vseukrainskoi naukovo-praktychnoi konferentsii, m. Kyiv, 15-16 kvitnia 2016 r. Kyiv: KNUKiM (pp. 62-67). 
culture, actively interacting with related fields of humanitarian knowledge and history, philosophy, cultural studies, ethnology, sociology.

Particular attention is paid by modern researchers to the study of authentic dance, the comprehension of figurative archetypes, regional cultural codes, zonal and local specificity of performance, and the influence of assimilation processes. Common terms are constantly being refined and new terms are introduced, which contributes to the achievement of terminological purity, the harmonization of scientific instruments with those established in European choreology. Ukrainian scientists use the foreign choreologists achievements. Thus, I. Mostova emphasizes, in particular, the productivity of using the experience of Polish choreologists to identify folk dances of Slobozhanshchina: "Based on the analysis of Polish scientists conceptualized the term "dance canon" to determine the dancing traditions features of Slobozhanshchina"7. The researcher states: "The term "dance canon" defines a system of folk dance signs, which allows identifying deep meanings and symbols during their broadcast and, forming one system, identifies dance with a nation, ethnographic group, and region", .

The concept of identifying dance with a nation, region, ethnographic group, etc. is at the heart of the vast majority in current research. Unlike Soviet art critics, who, by carefully examining the early forms of folk dance, relayed tendencies about the "common origins" of Russian, Ukrainian, and Belarussian dance, Ukrainian scholars, drawing on the experience of prominent national historians of the past (D. Antonovich, D. Bagaliy, F. Vovk, M. Hrushevsky, M. Maksimovich, V. Petrov, M. Sumtsov, I. Franko, D. Yavornitsky), the position and conclusions of modern historians, cultural scientists, ethnologists (I. Dzyuba, V. Borysenko, M. Grimich, O. Kurochkina, A. Ponomaryov, G. Skrypnyk, V. Smolia, M. Popovych, $\mathrm{N}$. Yakovenko), the achievements of world humanitarian studies reproduce the real picture of the evolution of folk choreographic culture.

V. Shkorinenko emphasized the need to understand the phenomena of folk and folk-choreography in a wide cultural context, one of the first in the Ukrainian post-Soviet choreology, recognizing as a primary task "the definition of approaches that would allow to conceptually justifying the traditional and the context of national and human culture" . Noting that onesidedness in the analysis of artistic forms of dance has caused a number of problems with its identification, B. Shkorinenko looks for the key to solving

${ }^{7}$ Mostova, I.S. (2019). Khudozhno-mystetski aspekty identyfikatsii narodnykh tantsiv Slobozhanshchyny v konteksti sotsiokulturnoho rozvytku rehionu. PhD Thesis. Kharkiv, p. 6.

${ }^{8}$ Ibid.

${ }^{9}$ Shkorinenko, V.O. (2003). Narodnyi tanets u tradytsiinii i suchasnii kulturi Ukrainy. PhD Thesis. Kyiv, p. 6. 
them in the methodological plane: "The most promising area is the rethinking and the systematization of research material from a cultural standpoint", the researcher says, - that is, the consideration of the dance art as an integral part of the overall process of ethno culture" 10 .

The methodological "retooling" process of Ukrainian choreology is ongoing. Its performance is evidenced by the research of O. Yelyokhina, K. Kinder, A. Korol, N. Marusyk, O. Merlianova, A. Morozov, I. Mostova. Thus, the use of the poly methodology principle, the phenomena comprehension of folk and folk-choreography at the junctions of different branches of humanitarian knowledge is choreology, philosophers, history, cultural studies, sociology, ethnology, ethno-psychology, religious education, theatrical education and music, peculiarities positions of dance art of Kyven Russ, in particular, dance art of buffoons ${ }^{11}$; K. Kinder is to reveal the semantics of plastic symbols of folk dance ${ }^{12}$; A. King is to interpret female characters in Ukrainian ballets in a new way, using the experience of modern ethno-choreology ${ }^{13}$; A. Morozov is to study the evolution of virtuoso movements in folk and folk-dance ${ }^{14}$. The principle of poly methodology was used by us to clarify a number of the theory provisions of artistic image, the basis of which is not always consistently substantiated and formulated by K. Vasylenko.

The mentioned and other works of young Ukrainian researchers, as well as numerous analytical articles and explorations published in scientific periodicals, materials of scientific and practical conferences, etc. testify to the qualitative growth of modern Ukrainian choreology. At the same time, we have to state that the process of accumulating material in Ukraine, which should be completed with the creation of generalizing works on the history of folk choreographic art, is somewhat delayed. In the sphere of theoretical, methodological and pedagogical literature, which in the days of independence was enriched by the works of K. Vasylenko, O. Zharov, S. Zabredovsky, S. Zubatov, A. Markovich, A. Tarakanova, O. Tarantseva, the lack of generalizing works of textbook character is keenly felt. Actually, whether or not there is only systematic

${ }^{10}$ Shkorinenko, V.O. (2003). Narodnyi tanets u tradytsiinii i suchasnii kulturi Ukrainy. PhD Thesis. Kyiv, p. 6.

${ }^{11}$ Yelyokhina, O.O. (1996). Problemy rozvytku tantsiuvalnoho mystetstva Ukrainy. Period Kyivskoi Rusi. PhD Thesis. Kyiv.

${ }^{12}$ Kinder, K.R. (2007). Semantyka plastychnykh symvoliv narodnoi tantsiuvalnoi kultury ukraintsiv. PhD Thesis. Kyiv.

13 Korol, A.M. (2019). Zhinochi obrazy v ukrainskykh baletakh. PhD Thesis. Kyiv: KNUKiM.

${ }^{14}$ Morozov, A.I. (2019). Virtuozni rukhy v ukrainskomu narodno- stsenichnomu tantsi. PhD Thesis. Kyiv: KNUKiM. 
textbook is "Ukrainian Dance" by K. Vasylenko", certain provisions and conclusions of which, formed under the Soviet art criticism influence, need correction. A productive attempt to create a textbook on the material of a particular region for students of specialized educational institutions of the first year study is the "methodology of teaching Ukrainian folk dance" by S. Zubatov ${ }^{16}$. However, manuals of this type, to some extent satisfying the demand, given the narrow coverage of the material, cannot compensate for the lack of generic, universal textbooks on folk choreographic art. Creating such author's or collective textbooks is a top priority for Ukrainian scientists.

The worst, in our opinion, is the case of literature addressed to the mass reader, whose purpose is to popularize Ukrainian dance, in accessible narratives to reveal to the general public its aesthetic perfection, ancient history, significance in the past and present life of the people. After all, mass consumers of different types of contemporary cultural product are unlikely to be interested in repertoire collections, theoretical and methodological developments, dissertations, articles in specialized collections, which are out of print and addressed to specialists, as well as anniversary presentations such as, for example, "Bukovina dance" ${ }^{17}$. Mass reader needs vivid stories about dances, documentary stories about outstanding choreographers and dancers. In our opinion, a positive example of such literature needed by society is O. Burkovsky's already mentioned story "Always on the Road" ${ }^{\text {" }}$. The text is a record of M. Vantukh's memoirs and reflections. The book is read with unwavering interest because it reveals the master's creative laboratory, contains emotionally charged thoughts, addressed not only to professionals but also to Ukrainian society. Unfortunately, we have very few such books, and they are badly needed. In the competition against mass culture, we are still losing in such an important segment as the popularization of folk choreographic art by means of literature.

\section{Questions of interaction of folk-stage and household dancing}

Ukraine is rightly proud of the outstanding choreographers' achievements and performers of folk-dance, whose list is headed by P. Virsky. Building his own artistic style based on the synthesis of folk dance and classical ballet, P. Virsky created choreographic masterpieces that are admired not only in Ukraine but also

\footnotetext{
${ }^{15}$ Vasylenko, K. (1997). Ukrainskyi tanets: pidruchnyk. Kyiv : IPKPK.

${ }^{16}$ Zubatov, S.L. (2017). Metodyka vykladannia ukrainskoho narodnoho antsiu: pidruchnyk. Kyvi: Lira.

17 Bukovynskyi tanets u zapysakh M. A. Pomorenskoho, Ya. P. Murakhovskoho, T.V. Suliatyzhkoho, M. H. Pupchenka. (2007). Chernivtsi: Vydavnychyi dim "Bukrek".

${ }^{18}$ Burkovskyi, O. (2013). Zavzhdy v dorozi: Dokumentalna povist pro M. Vantukha. Kyiv: Presa Plius.
} 
in many countries of the world, as evidenced by numerous reviews in the foreign press, given by the author of the article cited. M. Vantukh, who headed the P. Virsky Dance Ensemble after the master's death, has set himself the goal of preserving his classic heritage and creating, based on the aesthetic potential of these and those inheriting P. Virsky's traditions.

The cultural policy of the Soviet authorities consisted in the network development of professional and amateur ensembles of various levels, whose repertoire was tightly controlled, with the simultaneous consistent eradication of authentic folk dance as an important component of national custom in folk life and the replacement of its forms with surrogate innovations. The result of this cultural policy was, on the one hand, the achievement of a high level of dance skill in professional teams headed by K. Balogh, M. Vantukh, V. Verkhovynets, P. Virsky, O. Homon, L. Kalinin, O. Kolosk, A. Krivokhizha, D. Swallow, V. Marushchak, V. Mikhailov, Y. Chuperchuk the second is the decline of folk dance culture in the context of the general decline of folklore traditions that tried to replace them with false Soviet "traditions" in the format of "red calendar", "Komsomol wedding", etc. Mass folk dance was better preserved in Western Ukrainian lands, finally annexed to Soviet Ukraine after World War II, where assimilation processes and earlier historical periods were marked by lower dynamics than in the territory of "sub-Russian" Ukraine.

As of the early 2000s, a wide network of professional and amateur choreographic teams was operating in Ukraine: National Dance Ensemble named after P. Virsky (Kyiv), "Tavriya" (Simferopol), "Donbass" (Donetsk), "Nadzbruchanka" (Ternopil), "Zoryani" (Kirovohrad, now Kropyvnytskyi), "Slavuta" (Dnipropetrovsk, now - Dnipro), Verkhovyna (Lviv), Rodoslav (Zhytomyr), highly professional choreographic groups of the People's Choir named after G. Verevka, Transcarpathian, Volyn, Cherkasy folk choirs, Bukovyna, Chernihiv, Hutsul ensembles of songs and dances, Poltavskaya also about 20 thousand choreographic groups of different departments ${ }^{19}$.

In the past, the network of choreographic groups has undergone some changes. The Ukrainian choreographic groups in the annexed by the Russian Federation of Crimea and in the areas occupied by Donetsk and Lugansk regions ceased their activity; in new economic and socio-cultural circumstances, a number of ensembles were on the verge of survival, and some ceased operations.

In order to preserve national choreographic culture, develop performing traditions and popularize Ukrainian dance in new cultural realities at the

${ }^{19}$ Stan narodnoi khoreohrafii v Ukraini ta perspektyvy yii rozvytku: materialy naukovopraktychnoi konferentsii (28 liutoho 2002 r., m. Kyiv). (2002). Kyiv: Stylos, p. 5. 
initiative of leading masters, in 2002 an All-Ukrainian Choreographic Union was founded, headed by M. Vantukh, and the All-Ukrainian Festival of Folk Choreography was founded. These activities soon proved to be effective, but they are not enough for radical changes in the field of folk choreographic art, which, unlike contemporary choreography, which is actively developing in the context of show business, requires state care and material support. Independent Ukraine is defined by lack of clarity and weakness. "Unfortunately, we do not have a state policy in the field of culture and art", says M. Vantuh. - Everything is tossed, everyone does what they want. And this is under the slogan "We are going to Europe!" And will it not happen that while we run there, we will lose everything?"20

The process of national-cultural revival in Ukraine, for all its positives, turned out to be extremely dramatic. In the context of the traumatic breakdown of the old system of cultural management and the formation of fundamentally new forms of organization of cultural and artistic process and change of social priorities before the national choreography posed a real threat to be on the cultural periphery.

Leading oligarch-funded TV channels are removing folklore and folkdance from their programs, favoring contemporary choreography. "The passion for rhythm mania drove the folk dance from the repertoire of most amateur groups," - said A. Krivozhikha ${ }^{21}$. According to D. Demkiv, one of the most pressing issues of choreographic art was the "uncontrolled travel abroad of all kinds of concerts under the brand of "dance ensembles", which degraded the Ukrainian culture, glorified in the world thanks to the activities of the collectives named after P. Virsky, G. Veryovka and others ${ }^{22}$. A number of problems in professional preparation of students are noted by S. Zabredovsky, in particular:

" - One-sidedness of scientific-theoretical, professional knowledge, lack of their completeness in the field of Ukrainian folk choreographic art ;

- insufficient level of general geographical practical skills and skills for the fulfillment of future multifaceted artistic, creative and pedagogical activity;

${ }^{20}$ Burkovskyi, O. (2013). Zavzhdy v dorozi: Dokumentalna povist pro M. Vantukha. Kyiv: Presa Plius. p. 24.

${ }^{21}$ Kryvokhyzha, A.M. (2002). Problemy narodno-stsenichnoi khoreohrafii ta shliakhy yikh vyrishennia. In Stan narodnoi khoreohrafii v Ukraini ta perspektyvy yii rozvytku: materialy naukovo-praktychnoi konferentsii (28 liutoho 2002 r., m. Kyiv). Kyiv: Stylos (pp. 62-64).

${ }^{22}$ Demkiv, D.P. (2002). Problemy ta rozvytok ukrainskoi narodnoi khoreohrafii. In Stan narodnoi khoreohrafii $v$ Ukraini ta perspektyvy yii rozvytku: materialy naukovo-praktychnoi konferentsii (28 liutoho 2002 r., m. Kyiv). Kyiv: Stylos (pp. 42-43). 
- a narrow understanding of the content and nature of the functioning of folk choreographic art ..."23.

S. Zabredovsky emphasizes that the main factor of professional preparation of students is the motivational sphere, that is, a conscious choice of activity, which provides an asceticism element.

These and other problems, formulated by the participants of the stage in the recent history of Ukrainian dance of the conference "State of folk choreographic art in Ukraine and prospects for its development", have not lost their relevance today. The positive changes that have taken place since the conference (2002) mainly concerned the sphere of folk-dance and the use of Ukrainian dance in contemporary domestic culture is of concern. Understanding this problem and finding ways to solve it by harmonizing the two spheres: folk and stage dancing, given the rapid dynamics of urbanization processes and the onset of mass culture is a priority of the scientific environment, a society at large, building a European future that is bound by the obligation of the maintaining cultural values.

As you know, folk dance was formed in the context of national holidays of calendar and family cycles, the whole complex of traditional custom. Its functioning is ensured by the preservation of traditional culture elements in a particular region. Huge arrays of folk dances are associated with calendar holidays (spring dance); dance games related to the Kupala and New Year and Christmas holidays, ceremonial wedding dances (ceremonial and erotic). The names of the Bukovynian dances "In Chunkov at the temple" (Rzhavintsev village), "Wreath of Bukovyna dances in Toloka" (Mamaivtsi village), "At the Banylivka crowd" (Banylovo village), "Levenets temple festivals" (Leventsiv village) attest to their tethering not only to a particular locality, but also to certain work and religious traditions, marked by local identity ${ }^{24}$.

A valuable contribution to the treasury of national culture was made by Ukrainian choreographers, recording and re-enacting a large number of authentic dances, providing them with a long stage life. Field studies were carried out by V. Avramenko, K. Balogh, K. Vasylenko, V. Verkhovynets, P. Virsky, A. Krivokhizha, D. Lastovka, Y. Murakhovsky, M. Pomoryansky, and Y. Chuperchuk. In particular, K. Balog recorded and staged such Transcarpathian dances, such as "Rakovetsky twisted", "Chotyryanka",

${ }^{23}$ Zabredovskyi, S.H. (2002). Rozvytok motyvatsiinoi sfery studentiv - yak zaporuka pidvyshchennia yakosti navchannia. In Stan narodnoi khoreohrafii v Ukraini ta perspektyvy yii rozvytku: materialy naukovo-praktychnoi konferentsii (28 liutoho 2002 r., m. Kyiv). Kyiv: Stylos (pp. 31-36).

24 Bukovynskyi tanets u zapysakh M. A. Pomorenskoho, Ya. P. Murakhovskoho, T.V. Suliatyzhkoho, M. H. Pupchenka. (2007). Chernivtsi: Vydavnychyi dim "Bukrek", p. 25. 
"Fighting fun" (from the Irshava district), "Sheepdogs on Polonina" (Rakhiv district), "Droboyka" (Mizhhirsky district), Bereznyanka (Veliko Bereznyany district) ${ }^{25}$. More than 30 dances of Zaporizhzhya region recorded Z. Sizonenko ${ }^{26}$. This list can be continued for a very long time as evidence of the ascension of Ukrainian choreographers in the Soviet period of history. However, it should be remembered that at that time the process of preserving choreographic authenticity was carried out mainly in one direction and from the folk environment to the amateur or professional scene, since folklore, including choreographic, customs and rituals were more or less eradicated from the folk. Today, special attention is needed to ensure the movement in the opposite direction, that is, the relaying of Ukrainian folk dance from the stage to the national environment, hence its revival in the context of the general process of revival of traditions. The dynamics of this process in the aspect of choreography is still far behind the dynamics of the revival of the folk song treasures and let us remember at least the proliferation of Christmas carols in Ukraine today, which were recently banned by the totalitarian state.

\section{An image of Ukrainian dance in the media space}

Writing about the Ukrainian folk dance, researchers do not tire of repeating that it is a unique property of the spiritual culture of the nation and self-identification means, reflects the character of the people and its inherent features: cheerfulness, soft humor, lyricism, etc. All this is true, although the stereotypical formulations of the "love-loving nature", "the reflection of the struggle heroics and the grandeur of victories and the joy of creative work" that have transposed into modern texts from Soviet art, together with the stamp "sparkling dance", have long filled the rubble. All this is true, although the stereotypical formulations of the "love-loving nature", "the reflection of the struggle heroics and the grandeur of victories and the joy of creative work" that have transposed into modern texts from Soviet art, together with the stamp "sparkling dance", have long filled the rubble. Unfortunately, this is not how Ukrainian folk dance appears in the contemporary media space, in particular, in various musicals, TV shows, and kitsch.

During the breaking of the stereotypes of Soviet culture, the folk choreographic art, unilaterally interpreted individually in the context of the populist tradition of the nineteenth and early twentieth centuries, suffered from biased and sometimes destructive criticism, a continuation of which, in

25 Baloh, K.F. (2008). Tantsi Zakarpattia: Repertuarnyi zbirnyk. Uzhhorod: KP "Uzhhorodska miska drukarnia", p. 5.

${ }^{26}$ Chmil, V.A. (2005). Tantsi Zaporizkoho kraiu v obrobtsi Z. Syzonenka. Kyiv: Vydavnychyi budynok "MMD". 
particular, O. Raznik sees in the choreographic art of "socialist realism". Evaluating the activities of "similar to each other, as if water drops of amateur dance or "songs and dance" "ensembles", as well as a "network of "exemplary" professional choreographic collectives, which should not only show the flowering of national cultures in the USSR, but also indicate their own citizens, what and how the "Soviet man" should dance ${ }^{27}$, the cultural scientist did not mention the artistic achievements of the choreographic collectives. In his opinion, they were only "powerful amplifiers" of the hinged-embroidered stereotype of the Ukrainian.

Defending the idea of creating a modern nation, some researchers believe; that showing on the TV screen of diverse folklore activities accompanied by authentic dances, concerts by well-known choreographic groups (such TV projects were a characteristic phenomenon of the 1990s) draws Ukrainians into the patriarchal past. Folk dances are interpreted by cultural scientists of the postmodernist orientation as a surviving instrument of Ukrainian based on the classical literature models of the XIX - beginning of the XX centuries, as a return to the "sharovarshchina", which should be eliminated. However, according to L. Novikov, "the masses did not want to identify themselves with the proposed image of Ukraine and Ukrainians" 28 .

The critique of folklore activities in the media space contributed to the fact that in the early 2000s the folk dance disappeared from the screen of Ukrainian television, giving way to mass culture products. This phenomenon alarmed the choreographic community. Appealing to TV producers, Yu. Gureyev notes: "It would be desirable for them not to be scared of accusations of "hawksbill" (very often this term is used badly and intentionally to humiliate and destroy our culture) and would organize a series of educational programs for children (and not only!) ... and show (they were very bored!) broadcasts (at least from stock materials) with performances by the best professional groups, as well as song and dance ensembles and folk choirs where there is a dance group. "This would be a real contribution to the continuation of the cause for which the bright and light life of P. Virsky lived"29. The disappearance of Ukrainian folk dance from the TV screen is noted with alarm by D. Demkiv: "... Ukrainian television favors contemporary dance, variety sports, ballroom and folk choreography. If we had

${ }^{27}$ Riznyk, O. (1998). Tanets. In Narysy ukrainskoi populiarnoi kultury. Kyiv: UTsKD, p. 647.

${ }^{28}$ Novykova, L. \& Trymbach, S. (1998). Telebachennia. In Narysy ukrainskoi populiarnoi kultury. Kyiv: UTsKD, p. 677.

${ }^{29}$ Hureiv, Yu.I. (2002). Vykhovannia natsionalnoi svidomosti zasobamy khoreohrafii v dytiachomu samodiialnomu kolektyvi. In Stan narodnoi khoreohrafii v Ukraini ta perspektyvy yii rozvytku: materialy naukovo-praktychnoi konferentsii (28 liutoho 2002 r., m. Kyiv). Kyiv: Stylos, p. 96. 
previously had the opportunity to study television ... to study in the glorious ensembles of P. Virsky, G. Verevka choir, now there are no such programs" ${ }^{\text {30 }}$.

The quotes we have received are from the conference materials almost twenty years ago. Has the situation improved today? We are confident that it has not improved. "I am already sick of the so-called modern dance that has filled all television screens," admits M. Vantukh. - "Because what we see is not dance, it's show business, far from art and dance" 31 . Appreciating in general the interest of contemporary youth in dance, M. Vantukh notes onesidedness and at the same time points to the narrowness of this interest, which is formed by the television screen: "Today you can learn a lot about modern dances and watch them without leaving home, in numerous television projects: "Dancing everyone!", "Dancing with the stars", "Big dances", "Maidans", "Dirty dances". There is even a dance and social project "Free man is free land" ${ }^{32}$. The outstanding choreographer questions the aesthetic value of the choreographic television projects offered to the viewer: "In ballet, on stage, in television programs, you can make any production, but first of all, one should think about its moral and aesthetic component, remember the great influence of art on people, rather than spoiling the youth with a low-key spectacle, calling it a modern dance ${ }^{33}$.

In the context of the problem of the presentation of Ukrainian folk choreography in television programs, it should be clarified: dancing as a phenomenon of national culture disappeared, giving way to a parody image of Ukrainian folk dance in satirical programs, kitsch, etc. Observing individual kitschy on the TV screen with the use of elements of dance moves and national clothing, it is sometimes difficult to set the slippery boundary beyond which irony or satire turns into a vicious mockery of national culture when a Ukrainian is presented in the image of a misunderstood "little-haired" or "layered", who thoughtlessly has fun in "vodka-hopak" Ukraine. Unfortunately, researchers who have an inadequate understanding of the Ukrainian dance history, its role and significance in national culture, tend to perceive, treat abusive caricatures of dance as manifestations of postmodern irony. We analyzed this negative trend in one of the author's articles ${ }^{34}$, in particular, pointing out that the authors and

${ }^{30}$ Demkiv, D.P. (2002). Problemy ta rozvytok ukrainskoi narodnoi khoreohrafii. In Stan narodnoi khoreohrafii $v$ Ukraini ta perspektyvy yii rozvytku: materialy naukovo-praktychnoi konferentsii (28 liutoho 2002 r., m. Kyiv). Kyiv: Stylos, p. 43.

${ }^{31}$ Burkovskyi, O. (2013). Zavzhdy v dorozi: Dokumentalna povist pro M. Vantukha. Kyiv: Presa Plius.

${ }^{32}$ Ibid.

${ }^{33}$ Ibid.

${ }^{34}$ Boiko, O.S. (2017). Ukrainskyi narodnyi tanen u komediinykh teleshou: ironichna interpretatsiia chy vulharyzatsiia? Ukrainian Culture: the Past, Modern, Ways of Development, 24, 291-296. 
perpetrators of evil parodies are not so much in the "wildlife" as in the Ukrainian dance in general, consciously or unconsciously continuing the dubious tradition formed in the Russian Empire and fueled by the enemies of Ukraine today as one of the "hybrids".

Lexical "arsenal" we attribute parody dances as a "dance doublespeak" 35 . The use of such rust, as well as linguistic, can be justified in view of the artistic purpose of ridiculing certain rudiments of everyday culture. However, if in entertaining TV shows we see Ukrainian folk dance only in a caricatured, distorted way, then, given the lack of programs in the TV show presenting high artistic achievements of national choreographic art, it makes one speak of a dangerous trend. Considering the popularity of numerous show projects is "Quarter 95" on $1+1$ channel, "Diesel show" on ICTV, the Russian show, the hopes for radical shifts in the media space appear rather illusory. At least for now it should be noted that the vocabulary of Ukrainian folk dance has partly become today the material for the creation of a show-product of a cat character, such as the image of Verka Serdyuchka ${ }^{36}$.

\section{CONCLUSIONS}

Ukrainian folk-choreography is actively reforming in the context of creating a model of modern national culture, preserving and developing the artistic heritage of the past and responding to the present challenges. The introduction into the scientific circulation of significant arrays of factual material, the critical rethinking of the theoretical base developed by its predecessors, and the use of modern research methods have ensured the qualitative growth of Ukrainian chorological thought. The biggest problems of choreology include the problem of creating a generalized history of folk choreographic art and complex modern textbooks on choreography. Sharply lacking books addressed to the mass reader that would promote dance as a unique phenomenon of national culture, reveal its incorruptible aesthetic value and significance as a powerful means of asserting Ukrainian identity.

Even in difficult circumstances of political, economic and cultural crisis, professional and amateur groups are steadily growing creatively and present the best samples of folk-dance in Ukraine and abroad. Among the priorities of the choreographers are the problems of clearing the choreographic art from the rudiments of "socialist realism", as well as the creation of effective

35 Boiko, O.S. (2017). Ukrainskyi narodnyi tanen u komediinykh teleshou: ironichna interpretatsiia chy vulharyzatsiia? Ukrainian Culture: the Past, Modern, Ways of Development, 24, 291-296.

${ }^{36}$ Hrytsenko, O. (1998). Vierka Serdiuchka yak dzerkalo ukrainskoi kulturnoi transformatsii. In Heroi ta znamenytosti v ukrainskoi kultury. Kyiv: UTsKD (pp. 340-351). 
mechanisms of protection against the negative impact of globalization processes, counteracting the expansion of Russian culture in the context of "hybrid war".

Today one of the major challenges is the problem of popularizing folk dance in the media space. While Ukrainian folk-dance and folklore dance has virtually disappeared from television screens, numerous show projects offer the mass spectator often doubtful about the aesthetic dimension of contemporary choreography.

The dangerous tendency of today has been the use of elements of folk dance in satirical television projects that form an inadequate view not only of dance, but also of the national culture of Ukrainians.

\section{SUMMARY}

The section on extensive material highlights the overall picture of the transformation of folk choreographic art in Independent Ukraine. In particular, attention is paid to topical issues of choreographic thought, as well as issues of interaction of folk-stage and everyday dance. The image of Ukrainian dance in the media space is revealed in the light of the trends that determine the life of Ukrainian dance in modern society. Priorities in choreography and practical activity of choreographers have been outlined and priorities have been highlighted: problems of creating modern textbooks on choreography, popularization of values of folk dance art in literature and mass media, revival of Ukrainian dance not only on stage, but also in folk life. As one of the negative tendencies characteristic of the contemporary cultural and artistic process, the widespread practice of using mock (using the brand of ironic) use of folk dance vocabulary in satirical TV projects, kitsch has been analyzed.

\section{REFERENCES}

1. Baloh, K.F. (2008). Tantsi Zakarpattia: Repertuarnyi zbirnyk. Uzhhorod: KP "Uzhhorodska miska drukarnia".

2. Boiko, O.S. (2017). Ukrainskyi narodnyi tanen u komediinykh teleshou: ironichna interpretatsiia chy vulharyzatsiia? Ukrainian Culture: the Past, Modern, Ways of Development, 24, 291-296.

3. Bukovynskyi tanets u zapysakh M.A. Pomorenskoho, Ya. P. Murakhovskoho, T. V. Suliatyzhkoho, M. H. Pupchenka. (2007). Chernivtsi: Vydavnychyi dim "Bukrek".

4. Burkovskyi, O. (2013). Zavzhdy v dorozi: Dokumentalna povist pro M. Vantukha. Kyiv: Presa Plius.

5. Vasylenko, K. (1997). Ukrainskyi tanets: pidruchnyk. Kyiv : IPKPK.

6. Verkhovynets, V. (1990). Teoriia ukrainskoho narodnoho tantsiu: 5-te vyd., dopovnene. Kyiv: Muzychna Ukraina. 
7. Hrytsenko, O. (1998). Vierka Serdiuchka yak dzerkalo ukrainskoi kulturnoi transformatsii. In Heroi ta znamenytosti v ukrainskoi kultury. Kyiv: UTsKD (pp. 340-351).

8. Hureiv, Yu.I. (2002). Vykhovannia natsionalnoi svidomosti zasobamy khoreohrafii v dytiachomu samodiialnomu kolektyvi. In Stan narodnoi khoreohrafii $v$ Ukraini ta perspektyvy yii rozvytku: materialy naukovopraktychnoi konferentsii (28 liutoho 2002 r., m. Kyiv). Kyiv: Stylos (pp. 91-96).

9. Demkiv, D.P. (2002). Problemy ta rozvytok ukrainskoi narodnoi khoreohrafii. In Stan narodnoi khoreohrafii $v$ Ukraini ta perspektyvy yii rozvytku: materialy naukovo-praktychnoi konferentsii (28 liutoho 2002 r., m. Kyiv). Kyiv: Stylos (pp. 42-43).

10. Yelyokhina, O.O. (1996). Problemy rozvytku tantsiuvalnoho mystetstva Ukrainy. Period Kyivskoi Rusi. PhD Thesis. Kyiv.

11.Zabredovskyi, S.H. (2002). Rozvytok motyvatsiinoi sfery studentiv yak zaporuka pidvyshchennia yakosti navchannia. In Stan narodnoi khoreohrafii $v$ Ukraini ta perspektyvy yii rozvytku: materialy naukovopraktychnoi konferentsii (28 liutoho 2002 r., m. Kyiv). Kyiv: Stylos (pp. 31-36).

12.Zubatov, S.L. (2017). Metodyka vykladannia ukrainskoho narodnoho antsiu: pidruchnyk. Kyvi: Lira.

13. Kyrylenko, K.M. (2016). Tradytsii ta novatsii yak skladova innovatsiinoi kultury maibutnoho khoreohrafa. In Khoreohrafiia XXI stolittia: mystetskyi ta osvitnii potentsial: materialy Vseukrainskoi naukovopraktychnoi konferentsii (m. Kyiv, 15-16 kvitnia 2016 r.). Kyiv: KNUKiM (pp. 17-20).

14. Kinder, K.R. (2007). Semantyka plastychnykh symvoliv narodnoi tantsiuvalnoi kultury ukraintsiv. PhD Thesis. Kyiv.

15. Kozynko, L.L. (2016). Zberezhennia folklornykh tantsiuvalnykh tradytsii u praktytsi profesiinykh khoreohrafichnykh kolektyviv zakhidnoho rehionu Ukrainy. In Khoreohrafiia XXI stolittia: mystetskyi ta osvitnii potentsial: materialy Vseukrainskoi naukovo-praktychnoi konferentsii, m. Kyiv, 15-16 kvitnia 2016 r. Kyiv: KNUKiM (pp. 62-67).

16. Korol, A.M. (2019). Zhinochi obrazy v ukrainskykh baletakh. PhD Thesis. Kyiv: KNUKiM.

17. Kryvokhyzha, A.M. (2002). Problemy narodno-stsenichnoi khoreohrafii ta shliakhy yikh vyrishennia. In Stan narodnoi khoreohrafii $v$ Ukraini ta perspektyvy yii rozvytku: materialy naukovo-praktychnoi konferentsii (28 liutoho 2002 r., m. Kyiv). Kyiv: Stylos (pp. 62-64).

18. Morozov, A.I. (2019). Virtuozni rukhy v ukrainskomu narodnostsenichnomu tantsi. PhD Thesis. Kyiv: KNUKiM. 
19. Mostova, I.S. (2019). Khudozhno-mystetski aspekty identyfikatsii narodnykh tantsiv Slobozhanshchyny v konteksti sotsiokulturnoho rozvytku rehionu. PhD Thesis. Kharkiv.

20. Novykova, L. \& Trymbach, S. (1998). Telebachennia. In Narysy ukrainskoi populiarnoi kultury. Kyiv : UTsKD (pp. 667-686).

21. Riznyk, O. (1998). Tanets. In Narysy ukrainskoi populiarnoi kultury. Kyiv: UTsKD (pp. 645-654).

22. Skrypnyk, H.A. (2008). Istoriia ukrainskoi kultury: u 5 tomakh. T. 4. Kn. 1. Kyiv: Naukova dumka.

23. Stan narodnoi khoreohrafii $\mathrm{v}$ Ukraini ta perspektyvy yii rozvytku: materialy naukovo-praktychnoi konferentsii (28 liutoho 2002 r., m. Kyiv). (2002). Kyiv: Stylos.

24. Chmil, V.A. (2005). Tantsi Zaporizkoho kraiu v obrobtsi Z. Syzonenka. Kyiv: Vydavnychyi budynok "MMD”.

25. Shkorinenko, V.O. (2003). Narodnyi tanets u tradytsiinii i suchasnii kulturi Ukrainy. PhD Thesis. Kyiv.

\section{Information about the author:}

Olha Boiko,

Candidate of Arts, Associate Professor, Associate Professor of the Choreographic Art Department, Kyiv National University of Culture and Arts, 36, Y. Konovalets str., Kyiv, 01133, Ukraine http://orcid.org/0000-0001-4534-2201 